\section{Grafting Watermelon and Using Plastic Mulch to Control Verticillium Wilt Caused by Verticillium dahliae in Washington}

\author{
Sahar Dabirian, Debra Inglis, and Carol A. Miles ${ }^{1}$ \\ Mount Vernon Northwest Washington Research and Extension Center, \\ Washington State University, Mount Vernon, WA 98273
}

Additional index words. soilborne disease, rootstock, scion, fruit quality

\begin{abstract}
Verticillium wilt, caused by the soilborne fungus Verticillium dahliae, is a significant disease affecting watermelon (Citrullus lanatus) production in Washington State. This field study at three locations in Washington in 2015 compared verticillium wilt susceptibility, fruit yield and quality of nongrafted watermelon, and grafted plants grown with black plastic and clear plastic mulch. Overall for grafting treatments, area under disease progress curve (AUDPC) values were higher for nongrafted 'TriX Palomar' (765) than for 'TriX Palomar' grafted onto 'Super Shintosa' (132), 'Tetsukabuto' (178), or 'Just' (187). Overall for mulch, the AUDPC value was higher for plants grown with black plastic mulch (385) than for plants grown with clear plastic mulch (237). Overall for location, the AUDPC value was lowest at Eltopia (84), intermediate at Othello (182), and highest at Mount Vernon (680). At season end, more Verticillium microsclerotia were present in stems of nongrafted 'TriX Palomar' than in grafted treatment stems at Eltopia and Mount Vernon, but not at Othello. Differences in microsclerotia presence occurred only in the top or scion portion of the stem, but not in the graft union, rootstock, or crown portions of the stem. There was no difference due to mulch in regard to Verticillium microsclerotia detected in stem assays. After harvest, $V$. dahliae soil density under black plastic mulch increased 6-fold at Eltopia, 4.7-fold at Othello, and 1.9-fold at Mount Vernon. In contrast, $V$. dahiae soil density under clear plastic mulch was nearly identical to the level at planting at each location $(<1,2.6$, and 27 cfu/g at Eltopia, Othello, and Mount Vernon, respectively). There was a significant interaction between grafting and location for fruit yield such that there was no difference at Eltopia and Othello, but at Mount Vernon, yield of nongrafted 'TriX Palomar' was lower $(7.4 \mathrm{~kg} /$ plant) than for grafted plants (average $13.0 \mathrm{~kg} / \mathrm{plant})$. The number and weight of marketable fruit per plant were higher at Othello (4.0 and $27.65 \mathrm{~kg} / \mathrm{plant}$, respectively) than at Eltopia $(2.0$ and $12.23 \mathrm{~kg} / \mathrm{plant}$, respectively) and Mount Vernon $(2.2$ and $11.63 \mathrm{~kg} /$ plant, respectively). Fruit firmness was greater overall for all three grafted treatments (average 2.67 N) than for nongrafted 'TriX Palomar' $(2.20 \mathrm{~N})$, but there was no difference in total soluble solids (TSS) or lycopene content of fruit due to grafting. Yield, fruit firmness, and TSS did not differ due to mulch type; however, lycopene content was greater for plants grown with black plastic mulch than with clear plastic mulch at Eltopia. There was no difference in TSS due to location, but fruit firmness was lower at Eltopia and Othello (2.20 and $2.44 \mathrm{~N}$, respectively) than at Mount

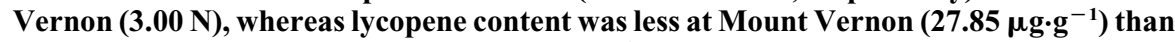
at Eltopia or Othello $\left(38.58\right.$ and $\left.36.54 \mu \mathrm{g} \cdot \mathrm{g}^{-1}\right)$. The results of this study indicate that although verticillium wilt symptoms were visible in watermelon plants when $V$. dahliae level was $<3 \mathrm{cfu} / \mathrm{g}$ of soil, watermelon yield was not reduced. However, when $V$. dahliae soil density was $>\mathbf{5 0} \mathrm{cfu} / \mathrm{g}$ of soil, yield was greater for grafted plants and for plants grown with clear plastic mulch.
\end{abstract}

\footnotetext{
Received for publication 3 Oct. 2016. Accepted for publication 1 Dec. 2016.

Funding support was provided by the Washington State Department of Agriculture SCBG No. K1506, USDA-NIFA SCRI No. 2011-51181-30963, Northwest Agricultural Research Foundation, Washington State Commission for Pesticide Registration, and State project WN00375-Acc. No.1008680.

Technical assistance provided by Patricia Kreider, Edward Scheenstra, and Todd Coffey are gratefully acknowledged.

${ }^{1}$ Corresponding author. E-mail: milesc@wsu.edu.
}

Verticillium wilt (caused by $V$. dahliae) is an important soilborne disease that limits watermelon ( $C$. lanatus) production in Washington State and worldwide (du Toit et al., 2005; Dung and Weiland, 2014; Johnson, 2012; Paplomatas et al., 2000; Paroussi et al., 2007; Sunseri and Johnson, 2001; Wimer et al., 2015). Once established in the field, $V$. dahliae is extremely difficult to manage because of its wide host range and long-lived survival structures (microsclerotia), which can persist in soil or plant debris for up to 14 years, and can remain viable up to $30^{\circ} \mathrm{C}$ (Berlanger and Powelson, 2000; Klosterman et al., 2009; Tjamos, 1989). Losses from verticillium wilt have led at least one major Washington grower to discontinue watermelon production, and other growers have experienced yield reduction of $25 \%$ to $75 \%$ (J. Loos and M. Nelson, personal communication, 2015). Preplant soil fumigation with methyl bromide had been used for over 50 years to control $V$. dahliae (Carpenter et al., 2000; Klosterman et al., 2009); however, methyl bromide was eliminated from use in most countries under the Montreal Protocol and as part of the Clean Air Act in the United States (Carpenter et al., 2000; U.S. Environmental Protection Agency, 2015). Other available soil fumigants such as Telone (1,3-dichloropropene + chloropicrin) and Vapam HL (metam sodium) are not always reliable for controlling $V$. dahliae (Davis et al., 2008; Klosterman et al., 2009; Woodward et al., 2011). As there is no resistance in watermelon against $V$. dahliae, alternative strategies that are environmentally sustainable are critically needed to achieve successful management.

Commercial grafting of cucurbits originated in the 1920s in Japan with the primary intent of managing soilborne pathogens (Oda, 2007; Sakata et al., 2007). The practice of grafting was expanded as a means to improve management of abiotic stresses (e.g., high soil salinity, drought, high temperature) to reduce the reliance on chemical and fertilizer inputs, and enhance fruit quality (Colla et al., 2010; Proietti et al., 2008). Today, grafting cucurbitaceous crops is an important integrated pest management strategy used worldwide to control several soilborne pathogens, including $V$. dahliae (Buller et al., 2013; Cohen et al., 2007; Davis et al., 2008; Guan et al., 2012; Louws et al., 2010), but has not been widely adopted in the United States, primarily because it is perceived as expensive and growers have limited knowledge about grafting (Cushman, 2009; Davis et al., 2008; Leonardi and Romano, 2004). Yet, researchers have consistently demonstrated that grafting can reduce severity of $V$. dahliae in watermelon (Johnson, 2012; King et al., 2008; Louws et al., 2010; Wimer et al., 2015). Grafting watermelon onto disease-tolerant rootstocks can delay onset of verticillium wilt symptoms by up to 3 weeks, thus allowing sufficient time for crop maturation (Paplomatas et al., 2002; Wimer et al., 2015). Paroussi et al. (2007) observed that verticillium wilt incidence decreased on grafted watermelon plants grown in artificially inoculated soil, and Buller et al. (2013) and Wimer et al. (2015) both observed reduced verticillium wilt severity of grafted watermelon plants at a naturally infested field site in western Washington harboring a relatively high soil population of $V$. dahliae $(18.0 \mathrm{cfu} / \mathrm{g})$

In addition to grafting, the use of plastic mulch is another alternative disease management practice. Although black polyethylene mulch is the standard mulch type used in vegetable production (Gordon et al., 2010), clear plastic mulch absorbs $5 \%$, reflects $11 \%$, 
and transmits $84 \%$ of radiation, thereby leading to higher soil temperature under the mulch (Gough, 2001; Tarara, 2000). Soil solarization can occur when temperature exceeds $30{ }^{\circ} \mathrm{C}$ and has been shown to be effective in controlling soilborne pathogens and nematodes, as well as weed seeds and seedlings (Elmore et al., 1997). Studies show that by using a clear plastic tarp on soil to achieve solarization, verticillium and fusarium wilts of several crops can be successfully controlled (Ashworth and Gaona 1982; Katan, 1984). Moreover, Rajablarijani and Aghaalikhani (2011) indicated that plants grown with clear plastic mulch had the highest early yields compared with plants grown with black and silver/black plastic mulch. In Washington, some watermelon growers sometimes use clear plastic mulch to increase plant growth rate, thereby decreasing days to maturity. The objective of this study was to investigate the efficacy of grafting onto disease-resistant rootstocks and using clear plastic mulch for controlling verticillium wilt in watermelon.

\section{Materials and Methods}

Experimental locations. A field experiment was carried out at three locations in Washington in 2015. Two of the locations were commercial watermelon farms in the Columbia Basin, one near Eltopia (soil type Taunton very fine sandy loam) and one near Othello (soil type Ephrata fine sandy loam) (University of California, 2010). At Eltopia, the summer climate is hot and dry, with an average daily temperature of $21^{\circ} \mathrm{C}\left(14{ }^{\circ} \mathrm{C}\right.$ minimum and $27^{\circ} \mathrm{C}$ maximum) and average daily relative humidity $(\mathrm{RH})$ of $48 \%$ [Washington State University (WSU) AgWeatherNet, 2016]. At Othello, the summer climate is also hot and dry, with an average daily temperature of $19{ }^{\circ} \mathrm{C}\left(11^{\circ} \mathrm{C}\right.$ minimum and $27{ }^{\circ} \mathrm{C}$ maximum) and average daily $\mathrm{RH}$ of 55\% (WSU AgWeatherNet, 2016). The third location was the WSU Northwestern Washington Research and Extension Center (NWREC) in Mount Vernon (soil type Skagit silt loam), where the summer is relatively cool and humid (University of California, 2010). The average daily summer temperature is $15{ }^{\circ} \mathrm{C}\left(10{ }^{\circ} \mathrm{C}\right.$ minimum and $21{ }^{\circ} \mathrm{C}$ maximum) and average daily $\mathrm{RH}$ is $79 \%$ (WSU AgWeatherNet, 2016).

Experimental design. At each location, the experiment was laid out in a split-plot design with four replications of two main plot treatments (24 plants each) and four subplot treatments (six plants each). Main plot treatments were black plastic and clear plastic mulch, and subplot treatments were nongrafted seedless watermelon cv. TriX Palomar (commonly grown by watermelon growers in Washington) and cv. TriX Palomar grafted onto 'Super Shintosa' (Cucurbita maxima $\times$ Cucurbita moschata), 'Tetsukabuto' (C. maxima $\times$ C. moschata), and 'Just' (Cucurbita hybrid). All transplants were grown and grafted at WSU NWREC. For Eltopia and Othello, TriX Palomar was sown on 24 Mar., rootstocks were sown on 8 Apr., and grafting occurred on 20 Apr. For Mount Vernon, TriX Palomar was sown on 23 Apr., rootstocks were sown on 4 May, and grafting occurred on 14 May. All seeds were sown into 72-cell trays filled with potting mix (Sunshine \#3 N \& O; Sun Gro Horticulture, Agawam, MA). The one-cotyledon grafting method described by Miles et al. (2016) was used for grafting all seedlings in this study. Immediately following grafting, plants were placed in a dark, closed healing chamber for $3 \mathrm{~d}\left(26.6{ }^{\circ} \mathrm{C}, 100 \%\right.$ humidity). Plants were acclimated by exposing them to greenhouse conditions for a progressively longer period of time each day for $6 \mathrm{~d}$, such that on day 9 after grafting, plants were fully exposed to greenhouse conditions.

Field plot preparation. At all three locations, beds were formed $(0.1-\mathrm{m}$ tall, $0.6-\mathrm{m}$ wide), with $1.5-\mathrm{m}$ center-to-center at Eltopia and Othello and 3-m center-to-center at Mount Vernon. Main plots were covered by hand with black plastic and clear plastic mulch (both $0.9 \mathrm{~mm}$; ClimaGro, Delhi, ON, Canada). Spacing between plants in the bed was $0.9 \mathrm{~m}$ at the three locations such that length of each main plot was $21.6 \mathrm{~m}$ and the length of each subplot was $5.4 \mathrm{~m}$. Plants were transferred to eastern Washington on 11 May, and transplanting occurred on 15 May at Eltopia and Othello, and on 2 June at Mount Vernon, following schedules typical for growers at each location. At Eltopia and Othello, the experiment was placed within a commercial watermelon field, whereas at Mount Vernon one row of 'TriX-Palomar' planted on each side of experiment served as the buffer. At all locations, 'Sugar Baby' was planted as the pollinizer at every third plant on the opposite side of each row. Pollinizer plants were not rated for verticillium wilt or harvested. At each location, soil temperature was measured (Hobo Onset, Bourne, MA) with probes placed $10 \mathrm{~cm}$ under the plastic mulch every $15 \mathrm{~min}$ in the middle of both main plots in the second replicate.

Also at each location, fertilizer and irrigation were applied following recommendations for the area (Hemphill, 2010). At Eltopia, fertilizer $(12 \mathrm{~N}-1.31 \mathrm{P}-0 \mathrm{~K}$; True Organic Products, Inc., Spreckles, CA) was applied before transplanting, on 11 May at $673 \mathrm{~kg} \cdot \mathrm{ha}^{-1}$. Fertilizer $(1 \mathrm{~N}-2.2 \mathrm{P}-0 \mathrm{~K}$; True Organic Products, Inc.) was additionally applied through drip irrigation on 3 and 5 June 2015 , at $605 \mathrm{~kg} \cdot \mathrm{ha}^{-1}$. Total nutrient application was $93 \mathrm{~N}-35.44 \mathrm{P}-0 \mathrm{~K} \mathrm{~kg} \cdot \mathrm{ha}^{-1}$. Drip tape $\left(0.833 \mathrm{~L} \cdot \mathrm{min}^{-1}, 31-\mathrm{cm}\right.$ emitter spacing; John Deere, San Marcos, CA) was laid on the center of the bed and irrigation was applied every $3 \mathrm{~d}$ for $8 \mathrm{~h}$. At Othello, the field had been cropped with alfalfa (Medicago sativa L.) for the prior 4 years and soil nutrients were adequate for growing watermelon (J. Loos, personal communication, 2015) so just one fertilizer (UAN $32 \mathrm{~N}-0 \mathrm{P}-$ $0 \mathrm{~K}$; Wilbur-Ellis, Aurora, CO) application through drip irrigation occurred in June at the rate of $56 \mathrm{~kg} \cdot \mathrm{ha}^{-1}$ for a total nutrient application of $18 \mathrm{~N}-0 \mathrm{P}-0 \mathrm{~K} \mathrm{~kg} \cdot \mathrm{ha}^{-1}$. Drip tape $\left(1.7 \mathrm{~L} \cdot \mathrm{min}^{-1}\right.$, 31-cm emitter spacing; Dunning Irrigation, Touchet, WA) was laid on the center of the bed and irrigation was applied every other day for $12 \mathrm{~h}$. At Mount Vernon, fertilizer $(8 \mathrm{~N}-$ 0.9P-3.3K; Nutri-rich, Wilber-Ellis, Aurora, CO) was applied at the rate of $1034 \mathrm{~kg} \cdot \mathrm{ha}^{-1}$ before transplanting, and fertilizer $(3 \mathrm{~N}-1.3 \mathrm{P}$ 2.5K; Biolink, Westbridge Agricultural Products, Inc., Visra, CA) was applied in the irrigation water at the rate of $106 \mathrm{~kg} \cdot \mathrm{ha}^{-1}$ starting $3 \mathrm{~d}$ after transplanting (DAT; 5 June) and once per week thereafter until 8 Aug., for a total of 10 applications. Total nutrient application was $115 \mathrm{~N}-23 \mathrm{P}-61 \mathrm{~K} \mathrm{~kg} \cdot \mathrm{ha}^{-1}$. Drip tape (1.29 L. $\mathrm{min}^{-1}$, T-Tape; John Deere, East Earl, PA) was laid on the center of each bed and plants were irrigated every $4 \mathrm{~d}$ for $2 \mathrm{~h}$.

Soil assays for Verticillium. At each location, one soil sample was collected from each subplot 2 weeks before transplanting and again 1 week after final harvest to estimate $V$. dahliae soil populations. Samples were taken to a depth of $15 \mathrm{~cm}$, bulked within each main plot at each location and sampling time, and placed on a bench in the greenhouse to dry before processing. One gram of dried soil from each bulked sample was dispersed uniformly over NP-10 agar (Kabir et al., 2004) plates using a salt shaker method with three replications for each location, modified from Butterfield and De Vay (1977); instead of wet-sieving, a mortar and pestle was used to ensure uniform spread of soil particles. Colonies of $V$. dahliae were counted after incubating the plates at $23{ }^{\circ} \mathrm{C}$ for $21 \mathrm{~d}$. Plates were examined using a dissecting microscope $(40 \times)$, and quantified for each main plot treatment at each location.

Verticillium assessments. At each location, symptoms of verticillium wilt (chlorosis, necrosis, and wilting) were rated visually on watermelon plants in each subplot every 2 weeks during the growing season; percent severity was recorded on a per plant basis and the average per plot was calculated. AUDPC values were calculated for each location and compared. At Eltopia and Othello, wilt ratings were recorded 42, 60, 70, and 83 DAT, with the first rating on 25 June and the last rating on 5 Aug. At Mount Vernon, ratings occurred $45,52,59,72$, and 89 DAT, with the first rating on 16 July and the last rating on 29 Aug. One week after harvest at all three locations, two of the most severely wilted plants from each subplot were collected and the stems were assayed for Verticillium microsclerotia. For each sampled plant, a $20-\mathrm{cm}$ stem sample that included the crown, and above the graft union for grafted plants, was surface sterilized using a $10 \%$ bleach solution and rinsed with deionized water. Each sample was cut in half longitudinally with a sterile knife to expose the vascular tissue, then placed in separate plastic boxes for incubation. After 4 weeks, samples were examined using a dissecting microscope $(40 \times)$ to determine whether Verticillium microsclerotia were present in the four parts of the stem. For grafted plants, these parts were the scion end of the stem, the graft union, the rootstock stem portion, and the 
rootstock crown. For nongrafted plants, the stem was visually divided into four segments that matched these four parts.

Fruit yield and quality. Harvest occurred on 5 Aug. at Eltopia and Othello, and on 4 Sept. at Mount Vernon. All fruit with a brown leaflet and tendril were considered ripe (Georgia Vegetable Team, 2000) and harvested, and the number and weight of marketable fruit and unmarketable fruit were recorded for each plant. Fruit quality was assessed for three marketable fruit that were randomly selected from each subplot the day after harvest. Each selected fruit was cut in half longitudinally, and from one half, a $25-\mathrm{cm}^{3}$ sample was taken from the center and flesh firmness [gramforce, reported as Newton $(\mathrm{N})]$ was measured to a depth of $1 \mathrm{~cm}$ with a drill-press penetrometer (Ametek, Berwyn, PA) fixed with a 4-mm cylindrical blunt-end tip. The reading was converted to $\mathrm{N}$ using the formula:

$$
x g f \times 0.00980665=\mathrm{N}
$$

Using the same fruit sample, the TSS (\%, measured as Brix) of the juice was measured using a digital refractometer (MISCO, Cleveland, $\mathrm{OH})$. Lycopene content $\left(\mu \mathrm{g} \cdot \mathrm{g}^{-1}\right)$ was determined using the spectrophotometer protocol modified from Nagata and Yamashita (1992). For this test, $50 \mathrm{~cm}^{3}$ was removed from the center of each fruit, then frozen at $-20{ }^{\circ} \mathrm{C}$ until used for the lycopene measurement. Samples were removed from the freezer and kept at room temperature $\left(23{ }^{\circ} \mathrm{C}\right)$ for $10 \mathrm{~min}$, then a clean mortar and pestle were used to homogenize each sample. Three 1-g subsamples were taken from each homogenized sample and placed in separate plastic centrifuge tubes wrapped in aluminum foil. Sixteen milliliters of a high-performance liquid chromatography grade $2: 3$ acetone:hexane solution was added to each tube. The tubes were agitated by hand for $1 \mathrm{~min}$ for thorough mixing, then returned back to the freezer for $1.5 \mathrm{~h}$. Tubes were removed from the freezer and left to rest for $5 \mathrm{~min}$ to separate the hexane and dissolved lycopene from the rest of the mixture. The hexane portion of each subsample was transferred to a cuvette using a disposable pipette, and the cuvette was placed in a spectrophotometer (DU Series 600; Backman Instruments, Inc., Fullerton, CA). The spectrophotometer was calibrated with a hexane blank before the first reading each day, and readings for each subsample were taken at 453, 505, 645, and $663 \mathrm{~nm}$ wavelengths. Lycopene content was calculated for each subsample using the equation below. Three subsample measurements were averaged for each fruit, and three fruit measurements were averaged for each plot.

$$
\begin{aligned}
& \text { Lycopene }\left(\frac{\mu \mathrm{g}}{\mathrm{g}} \text { fw sample }\right) \\
& =[(-0.0458 \times \mathrm{A} 663)+(0.204 \times \mathrm{A} 645) \\
& \quad+(0.372 \times \mathrm{A} 505)-(0.0806 \times \mathrm{A} 453)] \\
& \quad \times\left[\frac{10}{0.1042}\right]
\end{aligned}
$$

Data analysis. Data were subjected to analysis of variance using JMP software (version 11.0 for Windows; SAS Institute, Cary, NC). The main plot and the subplot treatments were explanatory variables, and fruit yield, fruit quality, and verticillium wilt severity were response variables. The AUDPC data and percent of infected stems for the three locations required transformation for statistical analysis (square root transformation was most appropriate in both cases). Multivariable logistic regression (logistic mixed model), with the three fixed effects (location, mulch, and rootstock) and a random effect for main plot, nested within the location-mulch combination in SAS software (version 9.4; SAS Institute) was used to analyze the probability of Verticillium microsclerotia presence in the stem samples. Treatment means were compared using Fisher's least significant difference test with a $5 \%$ level of significance.

\section{Results}

Soil temperature and Verticillium. The instruments used to measure soil temperature malfunctioned at all three locations, and although they were replaced, data collection was incomplete. Results presented are from 2 weeks after transplanting to 8 weeks after transplanting ( 2 weeks before harvest) at Eltopia; 2 weeks after transplanting to 10 weeks after transplanting (harvest) at Othello; and, from transplanting to 10 weeks after transplanting (2 weeks before harvest) at Mount Vernon. Average soil temperature under black plastic mulch tended to be lower than under clear plastic mulch at the three locations during these time periods: 23 vs. $25^{\circ} \mathrm{C}$, respectively, at Eltopia; 25 vs. $26{ }^{\circ} \mathrm{C}$, respectively, at Othello; and 25 vs. $30{ }^{\circ} \mathrm{C}$, respectively, at Mount Vernon (Fig. 1). At planting, V. dahliae colonies recovered from soil of each main plot were less than $1 \mathrm{cfu} / \mathrm{g}$ at Eltopia and Othello, and $28 \mathrm{cfu} / \mathrm{g}$ at Mount Vernon. After harvest, $V$. dahliae soil population densities under black plastic mulch increased to $4 \mathrm{cfu} / \mathrm{g}$ at Eltopia, $5 \mathrm{cfu} / \mathrm{g}$ at Othello, and $55 \mathrm{cfu} / \mathrm{g}$ at Mount Vernon. In contrast, $V$. dahiae soil density under clear mulch after harvest was similar to the level at planting at each location $(<1,3$, and $27 \mathrm{cfu} / \mathrm{g}$, respectively).
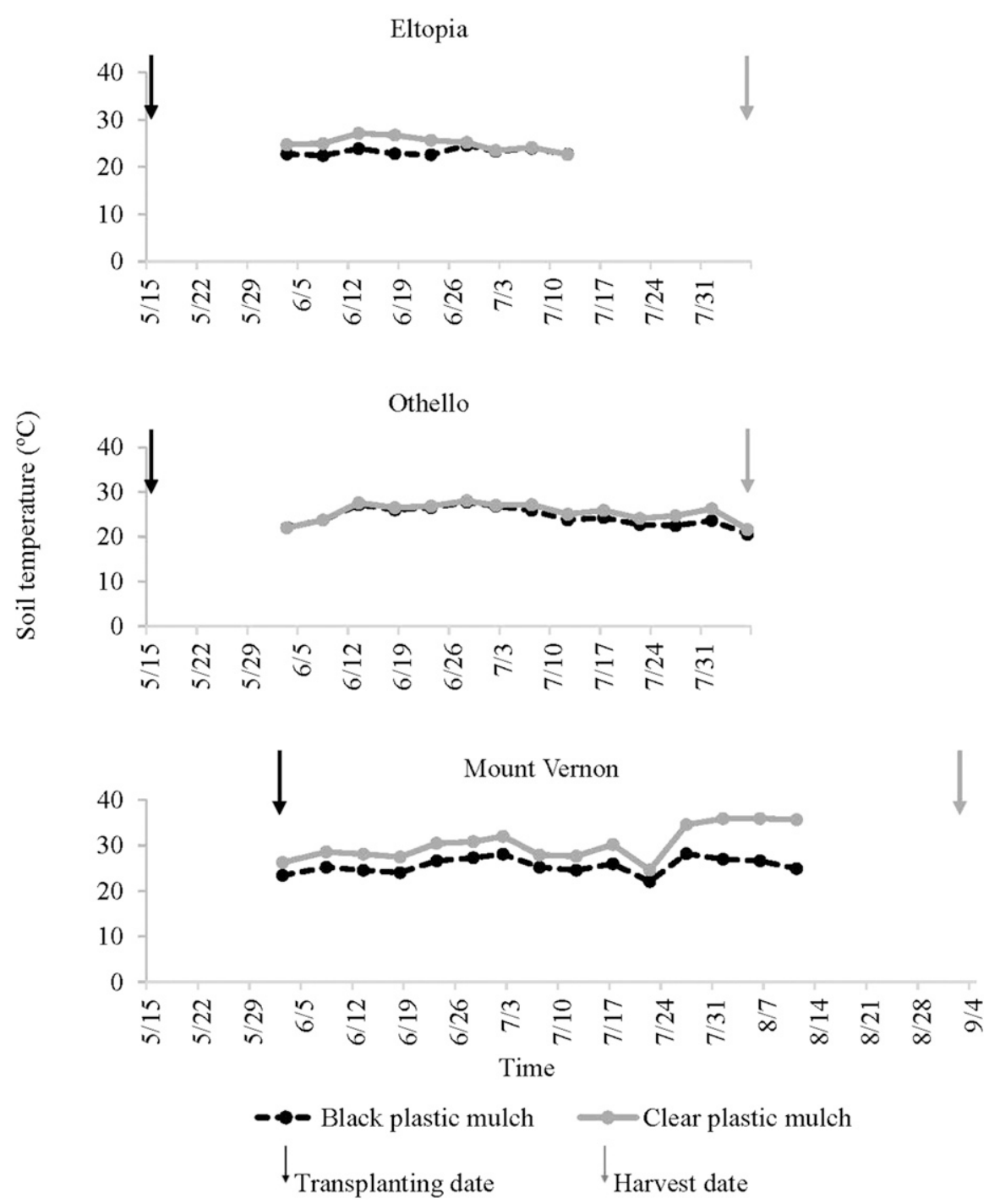

Fig. 1. Soil temperature $\left({ }^{\circ} \mathrm{C}\right)$ under black plastic and clear plastic mulch at Eltopia, Othello, and Mount Vernon in 2015. 
Verticillium assessments. Disease severity $(\%)$ over the growing season was higher for nongrafted 'TriX Palomar' than for the three grafted treatments grown with black plastic mulch at the three locations (Fig. 2). Nongrafted 'TriX Palomar' grown with clear plastic mulch also had more severe disease over the growing season than the three grafted treatments; yet, disease severity tended to be lower compared with black plastic mulch. The overall AUDPC value was higher for plants grown with black plastic mulch (385) than for plants grown with clear plastic mulch (237) $(P=0.0004)$, and this trend was the same at each location, although there was no significant difference among AUDPC values at Othello (Table 1). On average, AUDPC values were lowest at Eltopia (84), intermediate at Othello (182), and highest at Mount Vernon (680) $(P<$ 0.0001). Nongrafted 'TriX Palomar' also had higher average AUDPC values than grafted plants grown with both black plastic and clear plastic mulch treatments (Table 2). In addition, the AUDPC value for nongrafted 'TriX Palomar' was 2.4 times higher for black plastic mulch than clear plastic mulch treatments, whereas there were no differences for grafted plants due to mulch $(P=0.36)$. The overall AUDPC value for verticillium wilt was 4.6 times greater for nongrafted 'TriX Palomar' watermelon (765) than for the three grafted treatments (166 on average) $(P<$ 0.0001 ; Table 1). This trend was the same for each location, even though the AUDPC value of nongrafted 'TriX Palomar' at Mount Vernon was six times greater than at Eltopia and 3.4 times greater than at Othello. Although grafting in general resulted in lower AUDPC values at each location, at Eltopia plants grafted on 'Super Shintosa' had the lowest AUDPC value, there were no differences among the rootstocks for those at Othello and Mount Vernon.

Stem assays for Verticillium microsclerotia at the season's end showed no differences due to mulch treatment $(P=0.75)$. There were differences due to location $(P=$ $0.04)$ and grafting $(P<0.0001)$. In total, $32 \%$ of stem samples at Eltopia, 9\% at Othello, and $41 \%$ at Mount Vernon were positive for Verticillium microsclerotia. The incidence was higher for nongrafted 'TriX Palomar' than for grafted plants at both Eltopia $(P=$ $0.0007)$ and Mount Vernon $(P=0.0005)$, but not at Othello. Overall presence of Verticillium microsclerotia in the stems was greater for nongrafted 'TriX Palomar' (71\%) than for grafted 'TriX Palomar' (20\% on average) (Table 3). Location, mulch, and grafting had an effect on the probability of Verticillium microsclerotia presence in the top or scion portion of stem samples $(P=0.018, P=$ 0.015 , and $P<0.0001$, respectively), but there were no differences in the three other stem portions $(P>0.05)$. The probability of microsclerotia presence in the top or scion stem portion was 1.6 times greater at Eltopia than at Othello $(P=0.02)$, two times greater at Mount Vernon than at Othello $(P=0.006)$, but not different between Eltopia and Mount

Black plastic mulch
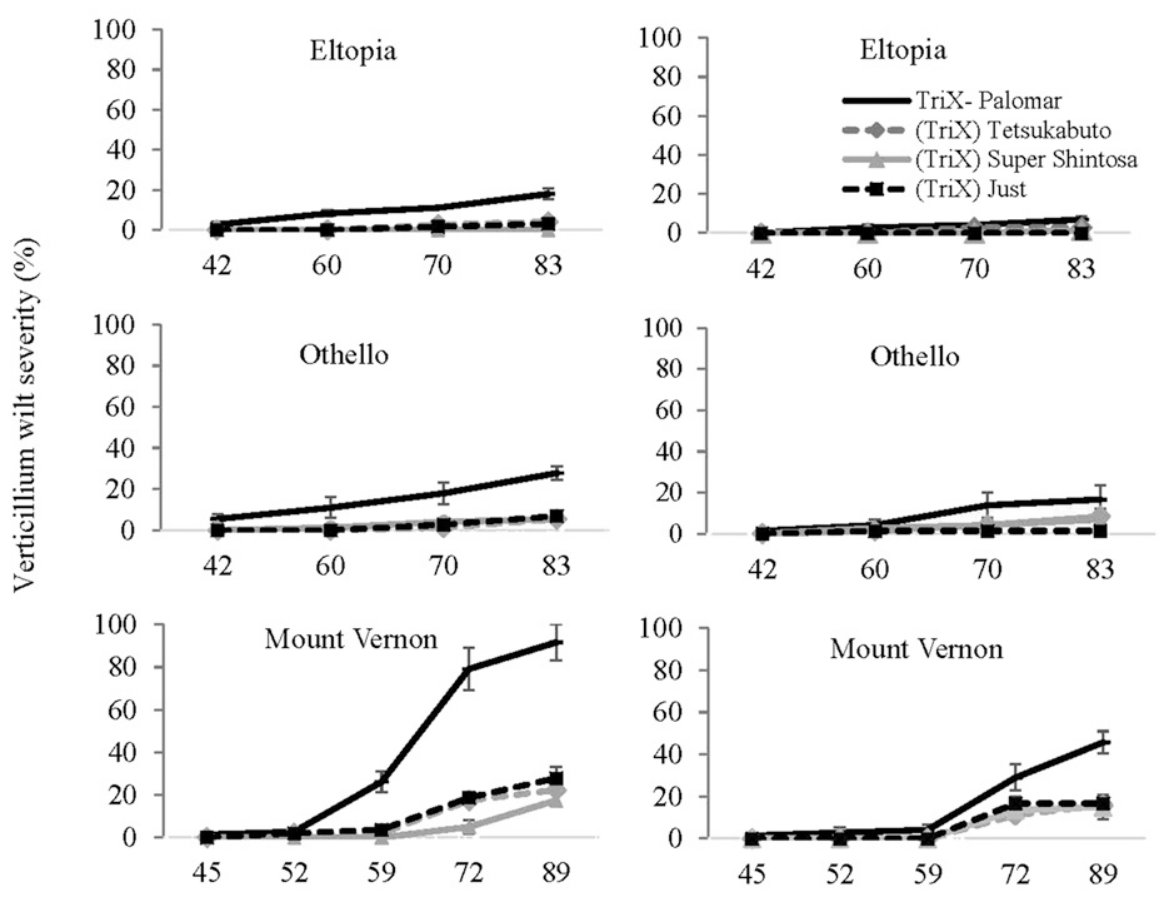

Days after transplanting

Fig. 2. Verticilium wilt severity (\%) for 'TriX Palomar' watermelon nongrafted and grafted onto commercial rootstocks 'Super Shintosa', 'Tetsukabuto', and 'Just' at Eltopia, Othello, and Mount Vernon, WA, in 2015. Severity was recorded as the percent of the plot canopy displaying typical verticillium wilt symptoms (chlorosis, necrosis, and wilting).

Table 1. Area under the disease progress curve (AUDPC) values for severity of verticillium wilt of watermelon grown with black and clear plastic mulch at Eltopia, Othello, and Mount Vernon in 2015. For mulch treatments AUDPC values were pooled for grafting treatment, and for grafting treatments AUDPC values were pooled for mulch treatments.

\begin{tabular}{lcccc}
\hline & & \multicolumn{3}{c}{ AUDPC value $^{\mathrm{z}}$} \\
\cline { 3 - 5 } Treatment & Overall AUDPC value & Eltopia & Othello & Mount Vernon \\
\hline Black mulch & 385 & 121 & 206 & 883 \\
Clear mulch & 237 & 47 & 159 & 477 \\
$P$ value & 0.0004 & 0.02 & 0.19 & 0.008 \\
TriX Palomar & $765 \mathrm{a}^{\mathrm{y}}$ & $258 \mathrm{a}$ & $465 \mathrm{a}$ & $1,570 \mathrm{a}$ \\
TriX (Super Shintosa) & $132 \mathrm{~b}$ & $5 . \mathrm{c}$ & $117 . \mathrm{b}$ & $257 . \mathrm{b}$ \\
TriX (Tetsukabuto) & $179 \mathrm{~b}$ & $54 \mathrm{~b}$ & $86 . \mathrm{b}$ & $395 \mathrm{~b}$ \\
TriX (Just) & $187 . \mathrm{b}$ & $20 . \mathrm{bc}$ & $60 \mathrm{~b}$ & $481 \mathrm{~b}$ \\
$P$ value & $<0.0001$ & $<0.0001$ & 0.0006 & $<0.0001$ \\
\hline
\end{tabular}

${ }^{\mathrm{z}}$ Disease severity was recorded as the percent of the plot canopy displaying wilt symptoms (chlorosis, necrosis, and wilting); AUDPC values were calculated based on verticillium wilt severity visual assessments taken on four rating dates at Eltopia and Othello, and five rating dates at Mount Vernon.

${ }^{\mathrm{y}}$ Mean separation letters is based on transformed ranked AUDPC values and were generated using the LSMeans statement in JMP (Version 11.0 for Windows; SAS Institute, Cary, NC) with $\alpha=0.05$; all means presented in the table are nontransformed. Treatments followed by the same letter within a column are not significantly different.

${ }^{\mathrm{x}}$ Rootstock cultivars of grafted plants are given in parentheses.

Vernon $(P=0.50)$. Further, the probability of microsclerotia presence in the top or scion portion of the stem was 1.3 times greater for plants grown with black plastic than with clear plastic mulch $(P=0.02)$. The probability of microsclerotia in the top or scion stem portion was greater $(P<0.0001)$ for nongrafted 'TriX Palomar' than for 'TriX Palomar' grafted onto 'Just' (3.4 times), 'Super Shintosa' (3.2 times), and 'Tetsukabuto' (2.2 times) (Table 4). Moreover, the probability of microsclerotia presence in the top or scion portion of the stem was 1.2 times greater for plants grafted onto 'Tetsukabuto' than onto 'Just' $(P=0.04)$, but there were no differences between 'Tetsukabuto' and 'Super Shintosa' or between 'Super Shintosa' and 'Just'.

Fruit yield and quality. Marketable fruit accounted for more than $99 \%$ of the fruit harvested at each of the three locations; hence, no unmarketable fruit yield data were collected. The overall marketable fruit yield was higher at Othello ( $27.7 \mathrm{~kg}$ per plant) than at Eltopia (12.2 kg per plant) and Mount Vernon $(11.6 \mathrm{~kg}$ per plant $)(P<0.0001)$ 
(Table 5). There were no significant differences in fruit yield due to mulch $(P=0.74)$ or grafting treatments $(P=0.81)$; however, there was an interaction between location and grafting $(P=0.02)$. At Eltopia and Othello, where Verticillium soil populations were relatively low, there was no significant difference in yield due to grafting $(P=0.37$ and $P=0.17$, respectively) (Table 6). In contrast at Mount Vernon, where Verticillium soil populations were relatively high, yield of nongrafted 'TriX Palomar' was lower $(7.4 \mathrm{~kg}$ per plant) than grafted treatments (average $13.0 \mathrm{~kg}$ per plant $)(P=0.009)$.

Flesh firmness $(\mathrm{N})$ differed due to location and was lower at Eltopia and Othello (2.20 N and $2.44 \mathrm{~N}$, respectively) than at Mount Vernon $(3.00 \mathrm{~N})(P<0.0001)$. There was no significant difference in fruit firmness due to mulch treatment $(P=0.15)$; however, there was an interaction between mulch and grafting treatments $(P=0.05)$. Although fruit firmness was lower overall for nongrafted 'TriX Palomar' $(2.20 \mathrm{~N})$ than for all three grafted treatments (average $2.67 \mathrm{~N})(P=$ 0.001 ), with black plastic mulch plants grafted onto 'Tetsukabuto' had the highest fruit firmness $(2.87 \mathrm{~N})$, and with clear plastic mulch plants grafted onto 'Super Shintosa' had the highest fruit firmness $(2.81 \mathrm{~N})$ (Table 7). There was no significant difference in TSS due to location (range was $10.28 \%$ to $10.51 \% ; P=0.25$ ), mulch (range was $10.39 \%$ to $10.50 \% ; P=0.41$ ), or grafting treatments (range was $10.23 \%$ to $10.62 \% ; P=0.38$ ). However, there was a significant interaction between location and grafting $(P=0.04)$, and nongrafted 'TriX Palomar' tended to have the highest TSS at Eltopia and Mount Vernon and the lowest at Othello (Table 8). There was a significant difference in lycopene content due to location $(P<0.0001)$; lycopene was less at Mount Vernon $\left(27.85 \mu \mathrm{g} \cdot \mathrm{g}^{-1}\right)$ than at Eltopia or Othello (38.58 and $36.54 \mu \mathrm{g} \cdot \mathrm{g}^{-1}$, respectively). There was no difference in lycopene content due to mulch $(P=0.21)$ or grafting treatments $(P=0.35)$; however, there was a significant interaction between location and mulch treatment $(P=0.01)$. At Eltopia, lycopene was greater in fruit grown with black plastic mulch $\left(42.22 \mu \mathrm{g} \cdot \mathrm{g}^{-1}\right)$ than with clear plastic mulch $\left(34.47 \mu \mathrm{g} \cdot \mathrm{g}^{-1}\right)(P=$ 0.01 ; Table 9). There were no differences in lycopene content due to the mulch treatment at Othello or Mount Vernon.

\section{Discussion and Conclusions}

In this study, verticillium wilt severity was greater for nongrafted 'TriX Palomar' watermelon than for the three grafted watermelon treatments by the end of the growing season at all three locations. Stem assays demonstrated that presence of Verticillium microsclerotia was greater for nongrafted 'TriX Palomar' than for grafted plants at Mount Vernon and Eltopia, but not at Othello. The probability of Verticillium microsclerotia being present in the top portion of the stem of nongrafted 'TriX Palomar' was 2-3 times greater than for the scion
Table 2. Area under disease progress curve (AUDPC) values for verticillium wilt of nongrafted 'TriX Palomar' watermelon and 'TriX Palomar' grafted onto the commercial rootstocks 'Super Shintosa', 'Tetsukabuto', and 'Just', and grown with black and clear plastic mulch in 2015 (data pooled for Eltopia, Othello, and Mount Vernon locations).

\begin{tabular}{lcc}
\hline & \multicolumn{3}{c}{ AUDPC values $^{z}$} \\
\cline { 2 - 3 } Treatment $^{\mathrm{y}}$ & Black mulch & Clear mulch \\
\hline TriX Palomar & $1,077 \mathrm{a}^{\mathrm{x}}$ & $453 \mathrm{a}$ \\
TriX (Super Shintosa) & $109 \mathrm{~b}$ & $156 \mathrm{~b}$ \\
TriX (Tetsukabuto) & $199 \mathrm{~b}$ & $158 \mathrm{~b}$ \\
TriX (Just) & $229 \mathrm{~b}$ & $145 \mathrm{~b}$ \\
$\quad P$ value & $<0.0001$ & 0.0003 \\
\hline
\end{tabular}

${ }^{\mathrm{z}}$ Disease severity was recorded as the percent of the plot canopy displaying wilt symptoms (chlorosis, necrosis, and wilting); AUDPC values were calculated based on verticillium wilt severity visual assessments taken on and four rating dates at Eltopia and Othello, and five rating dates at Mount Vernon. ${ }^{\mathrm{y}}$ Rootstock cultivars of grafted plants are given in parentheses.

${ }^{\mathrm{x}}$ Mean separation letters are based on transformed ranked AUDPC values and were generated using the LSMeans statement in JMP (Version 11.0 for Windows; SAS Institute, Cary, NC) with $\alpha=0.05$; all means presented in the table are nontransformed. Treatments followed by the same letter within a column are not significantly different.

Table 3. Incidence (\%) of stems positive for Verticillium microsclerotia, in nongrafted 'TriX Palomar' watermelon and 'TriX Palomar' grafted onto the commercial rootstocks 'Super Shintosa', 'Tetsukabuto', and 'Just' at Eltopia, Othello, and Mount Vernon in 2015 (data are pooled for black and clear plastic mulch treatments).

\begin{tabular}{lcccc}
\hline & Overall disease & \multicolumn{3}{c}{ Incidence (\%) of stems with microsclerotia } \\
\cline { 2 - 5 } Treatment ${ }^{\mathrm{z}}$ & $71.35 \mathrm{a}^{\mathrm{y}}$ & Eltopia & Othello & Mount Vernon \\
\hline TriX Palomar & $21.88 \mathrm{~b}$ & $23.1 \mathrm{a}$ & 37.5 & $87.5 \mathrm{a}$ \\
TriX (Super Shintosa) & $21.35 \mathrm{~b}$ & $40.6 \mathrm{~b}$ & 32.8 & $9.4 \mathrm{~b}$ \\
TriX (Tetsukabuto) & $17.19 \mathrm{~b}$ & $12.5 \mathrm{~b}$ & 1.6 & $21.9 \mathrm{~b}$ \\
TriX (Just) & $<0.0001$ & 0.0007 & 18.8 & $20.3 \mathrm{~b}$ \\
$P$ value & &
\end{tabular}

${ }^{\mathrm{z}}$ Rootstock cultivars of grafted plants are given in parentheses.

${ }^{\mathrm{y}}$ Mean separation letters are based on transformed ranked area under disease progress curve values and were generated using the LSMeans statement in JMP (Version 11.0 for Windows; SAS Institute, Cary, NC) with $\alpha=0.05$; all means presented in the table are nontransformed. Treatments followed by the same letter within a column are not significantly different.

Table 4. The probability of Verticillium microsclerotia presence in the top or scion portion of the stem, for location, mulch, and grafting treatments.

\begin{tabular}{lllcc}
\hline & \multicolumn{1}{c}{ Presence } & \multicolumn{2}{c}{$\begin{array}{c}\text { Probability of presence of } \\
\text { Verticillium dahliae }\end{array}$} \\
\cline { 3 - 5 } & \multicolumn{1}{c}{ Absence } & \multicolumn{1}{c}{ Odds ratio } & $P>\chi^{2}$ \\
\hline Location & Othello & Eltopia & 1.56 & 0.023 \\
& Othello & Mount Vernon & 1.93 & 0.006 \\
& Eltopia & Mount Vernon & 0.38 & 0.50 \\
Mulch & Clear & Black & 1.31 & 0.016 \\
Grafting & TriX (Super Shintosa) & TriX Palomar & 3.23 & $<0.0001$ \\
& TriX (Tetsukabuto) & TriX Palomar & 2.22 & $<0.0001$ \\
& TriX (Just) & TriX Palomar & 3.43 & $<0.0001$ \\
& TriX (Super Shintosa) & TriX (Tetsukabuto) & 1.02 & 0.069 \\
& TriX (Just) & TriX (Tetsukabuto) & 1.21 & 0.037 \\
& TriX (Just) & TriX (Super Shintosa) & 0.20 & 0.754 \\
\hline
\end{tabular}

${ }^{\mathrm{z}}$ Multivariable logistic regression (logistic mixed model), with the three fixed effects (location, $P=0.018$; mulch, $P=0.015$; grafting, $P<0.0001$ ) and a random effect for main plot, nested within the locationmulch combination, conducted in SAS (Version 9.4; SAS Institute, Cary, NC) to estimate the probability of Verticillium microsclerotia presence in the scion portion of stem samples. The general $\chi^{2}$ was 0.96 . ${ }^{\mathrm{y}}$ Rootstock cultivars of grafted plants are given in parentheses.

Table 5. Marketable fruit number and yield (kg) per plant at Eltopia, Othello, and Mount Vernon in 2015 (data pooled for black and clear plastic mulch treatments and for nongrafted 'TriX Palomar' and 'TriX Palomar' grafted onto the commercial rootstocks 'Super Shintosa', 'Tetsukabuto', and 'Just').

\begin{tabular}{lcc}
\hline Location & Fruit no. per plant ${ }^{\mathrm{z}}$ & Fruit yield per plant $(\mathrm{kg})$ \\
\hline Eltopia & $1.97 \mathrm{~b}^{\mathrm{y}}$ & $12.23 \mathrm{~b}$ \\
Othello & $4.02 \mathrm{a}$ & $27.65 \mathrm{a}$ \\
Mount Vernon & $2.19 \mathrm{~b}$ & $11.63 \mathrm{~b}$ \\
$P$ value & $<0.0001$ & $<0.0001$
\end{tabular}

${ }^{\mathrm{z}}$ Greater than $99 \%$ of fruit were marketable at all three locations.

${ }^{\mathrm{y}}$ Mean separation letters are based on ranked yield values and were generated using the LSMeans statement in JMP (Version 11.0 for Windows; SAS Institute, Cary, NC) with $\alpha=0.05$; all means presented in the table are nontransformed. Treatments followed by the same letter within a column are not significantly different. 
Table 6. Marketable fruit yield $(\mathrm{kg})$ per plant of nongrafted 'TriX Palomar' watermelon and 'TriX Palomar' grafted onto the commercial rootstocks 'Super Shintosa', 'Tetsukabuto', and 'Just' at Eltopia, Othello, and Mount Vernon in 2015 (data pooled for black and clear plastic mulch treatments).

\begin{tabular}{lccc}
\hline & \multicolumn{3}{c}{${\text { Fruit yield per plant }{ }^{\mathrm{z}}(\mathrm{kg})}$} \\
\cline { 2 - 4 } Treatment $^{\mathrm{y}}$ & Eltopia & Othello & Mount Vernon $^{-}$ \\
\hline TriX Palomar & 14.66 & 30.37 & $7.39 \mathrm{~b}^{\mathrm{x}}$ \\
TriX (Super Shintosa) & 12.15 & 28.08 & $14.60 \mathrm{a}$ \\
TriX (Tetsukabuto) & 11.03 & 28.73 & $11.81 \mathrm{a}$ \\
TriX (Just) & 11.06 & 23.44 & $12.69 \mathrm{a}$ \\
$\quad P$ value & 0.37 & 0.17 & 0.009 \\
\hline
\end{tabular}

${ }^{\mathrm{z}}$ Greater than $99 \%$ of fruit were marketable at all three locations.

${ }^{\mathrm{y}}$ Rootstock cultivars of grafted plants are given in parentheses.

${ }^{\mathrm{x}}$ Mean separation letters are based on ranked yield values and were generated using the LSMeans statement in JMP (Version 11.0 for Windows; SAS Institute, Cary, NC) with $\alpha=0.05$; all means presented in the table are nontransformed. Treatments followed by the same letter within a column are not significantly different.

Table 7. Mean watermelon flesh firmness $(\mathrm{N})$ for nongrafted 'TriX Palomar' watermelon and 'TriX Palomar' grafted onto the commercial rootstocks 'Super Shintosa', 'Tetsukabuto', and 'Just' grown with black plastic and clear plastic mulch in 2015 (data pooled for Eltopia, Othello, and Mount Vernon locations).

\begin{tabular}{lccc}
\hline & & \multicolumn{2}{c}{ Firmness (N) } \\
\cline { 3 - 4 } Treatment $^{\mathrm{z}}$ & Overall firmness (N) & Black mulch & Clear mulch \\
\hline TriX Palomar & $2.20 \mathrm{~b}^{\mathrm{y}}$ & $2.22 \mathrm{~b}$ & $2.17 \mathrm{a}$ \\
TriX (Super Shintosa) & $2.63 \mathrm{a}$ & $2.45 \mathrm{~b}$ & $2.81 \mathrm{a}$ \\
TriX (Tetsukabuto) & $2.75 \mathrm{a}$ & $2.87 \mathrm{a}$ & $2.64 \mathrm{ab}$ \\
TriX (Just) & $2.62 \mathrm{a}$ & $2.36 \mathrm{~b}$ & $2.87 \mathrm{~b}$ \\
$\quad P$ value & 0.001 & 0.001 & 0.034 \\
\hline
\end{tabular}

${ }^{\mathrm{z}}$ Rootstock cultivars of grafted plants are given in parentheses.

${ }^{\mathrm{y}}$ Mean separation letters are based on ranked firmness values and were generated using the LSMeans statement in JMP (Version 11.0 for Windows; SAS Institute, Cary, NC) with $\alpha=0.05$; all means presented in the table are nontransformed. Treatments followed by the same letter within a column are not significantly different.

Table 8. Total soluble solids (TSSs) for nongrafted 'TriX Palomar' and 'TriX Palomar' watermelon grafted onto the commercial rootstocks 'Super Shintosa', 'Tetsukabuto', and 'Just' at Eltopia, Othello, and Mount Vernon in 2015 (data pooled for black and clear plastic mulch treatments).

\begin{tabular}{lccc}
\hline & \multicolumn{3}{c}{ TSS (\%) } \\
\cline { 2 - 4 } Treatment $^{\mathrm{z}}$ & Eltopia & Othello & Mount Vernon \\
\hline TriX Palomar & $10.64^{\mathrm{y}}$ & 10.17 & 11.04 \\
TriX (Super Shintosa) & 10.37 & 10.35 & 10.27 \\
TriX (Tetsukabuto) & 10.05 & 10.70 & 10.25 \\
TriX (Just) & 10.07 & 10.94 & 10.50 \\
$P$ value & 0.40 & 0.08 & 0.06 \\
\hline
\end{tabular}

${ }^{\mathrm{z}}$ Rootstock cultivars of grafted plants are given in parentheses.

${ }^{\mathrm{y}}$ Mean separation is based on ranked TSS values and was generated using the LSMeans statement in JMP (Version 11.0 for Windows; SAS Institute, Cary, NC) with $\alpha=0.05$; all means presented in the table are nontransformed.

Table 9. Lycopene $\left(\mu \mathrm{g} \cdot \mathrm{g}^{-1}\right)$ for nongrafted 'TriX Palomar' watermelon and 'TriX Palomar' grafted onto the commercial rootstocks 'Super Shintosa', 'Tetsukabuto', and 'Just' grown with black plastic and clear plastic mulch at Eltopia, Othello, and Mount Vernon in 2015 (data pooled for nongrafted 'TriX Palomar'and 'TriX Palomar' grafted onto the commercial rootstocks 'Super Shintosa' and 'Tetsukabuto').

\begin{tabular}{lccc}
\hline & \multicolumn{3}{c}{ Lycopene $\left(\mu \mathrm{g} \cdot \mathrm{g}^{-1}\right)$} \\
\cline { 2 - 4 } Treatment & Eltopia & Othello & Mount Vernon \\
\hline Black mulch & $42.22^{\mathrm{z}}$ & 35.59 & 27.58 \\
Clear mulch & 34.47 & 37.49 & 28.11 \\
$P$ value & 0.01 & 0.08 & 0.78 \\
\hline
\end{tabular}

${ }^{\mathrm{z}}$ Mean separation is based on ranked TSS values and was generated using the LSMeans statement in JMP (Version 11.0 for Windows; SAS Institute, Cary, NC) with $\alpha=0.05$; all means presented in the table are nontransformed.

portion of grafted 'TriX Palomar'. There were no differences among treatments for other parts of the stem. These results are similar to previous studies, which have shown that grafting can reduce Verticillium infection in cucurbitaceous crops in general plants grown with black plastic mulch than with clear plastic mulch at Eltopia and Mount Vernon. In addition, the probability of Verticillium microsclerotia presence in the top or scion portion of the stem was 1.3 times greater for plants grown with black plastic than with clear plastic mulch.

After harvest, $V$. dahliae population density in the soil under black plastic mulch increased $\approx 2$-fold at Mount Vernon and Othello and 4-fold at Eltopia. In contrast, at the end of the growing season, $V$. dahliae population density in the soil under clear plastic mulch was nearly identical to the level at planting at each of the three locations. This result was likely due to soil temperatures which tended to be $1-5^{\circ} \mathrm{C}$ higher under clear plastic mulch than under black plastic mulch. It is interesting to note that there was also very little weed growth under the clear plastic mulch at all three locations. Other studies have shown that clear plastic mulch can transmit $84 \%$ of radiation, and can increases soil temperature by $5{ }^{\circ} \mathrm{C}$ or more (Ashworth and Gaona, 1982; Elmore et al., 1997; Gough, 2001; Katan, 1984; Tarara, 2000). At Mount Vernon, the plant canopy was somewhat small due to slower plant growth rate and greater disease pressure, and covered only a portion of the bed. Thus, more of the mulch surface was exposed at this location, and the average temperature under the mulch was higher than at the other two locations even though the average daily temperature was lower. Calderon et al. (2014) found that a temperature range of 16 to $24{ }^{\circ} \mathrm{C}$ was most favorable for $V$. dahliae infection of olive, but studies have not been done to determine a threshold soil temperature for infection in watermelon. Other studies have shown, however, that by using a clear plastic tarp to solarize soil, verticillium and fusarium wilts of cucumber (Cucumis sativus), tomato (Solanum lycopersicum), and strawberry (Fragaria ananassa) can be successfully controlled (Ashworth and Gaona, 1982; Katan, 1984).

In the current study, fruit yield was not different due to grafting or mulch type at Eltopia and Othello, where the $V$. dahliae soil population density at the end of the growing season was 4 and $5 \mathrm{cfu} / \mathrm{g}$, respectively. In contrast, at Mount Vernon, where the $V$. dahliae soil population density was $55 \mathrm{cfu} /$ $\mathrm{g}$, yield was greater for grafted plants. These results are similar to other studies in the region that found that watermelon yield was not reduced when $V$. dahliae soil population density was $1-3 \mathrm{cfu} / \mathrm{g}$, but yield was reduced when levels were greater than $18-27 \mathrm{cfu} / \mathrm{g}$ (Buller et al., 2013; Wimer et al., 2015). Xu et al. (2005), Qi et al. (2006), and Wu et al. (2006) also reported that grafted muskmelon (Cucumis melo L.) can have an improved yield when fusarium wilt is present and rootstocks are resistant. The authors found that this was due to grafted plants having stronger root systems and increased photosynthesis.

Fruit quality parameters are important for assessing market acceptability of grafted
(Cohen et al., 2007; Davis et al., 2008; Guan et al., 2012; Louws et al., 2010) and watermelon specifically (Buller et al., 2013; Johnson, 2012; King et al., 2008; Louws et al., 2010; Wimer et al., 2015). Moreover, in this study, verticillium wilt severity was greater for 
watermelon (Colla et al., 2010; Proietti et al., 2008). In the current study, similar to other studies of grafted watermelon, only watermelon flesh firmness was affected by grafting, and was lower overall for nongrafted 'TriX Palomar' than for the three grafted treatments (Buller et al., 2013; Wimer et al., 2015). Other studies have also found that watermelon fruit produced on plants grafted with hybrid squash rootstocks (C. maxima $\times$ C. moschata) can have higher firmness than fruit produced on nongrafted plants (HuitronRamirez et al., 2009; Lee, 1994; Paroussi et al., 2007). Bruton et al. (2009) found that flesh firmness was the only fruit quality characteristic affected when watermelon was grafted onto Cucurbita ficifolia, an interspecific hybrid squash rootstock. Also similar to other studies in the same region, in the current study there was a significant difference in lycopene content due to location (Buller et al., 2013; Wimer et al., 2015). At Mount Vernon, where the summer is relatively cool and humid, the lycopene content was less than at Eltopia or Othello, where the summer climate is hot and dry. Other research studies have shown that environmental conditions, such as season, location, soil fertility, irrigation, light intensity, and day/ night temperatures, as well as harvest maturity and vine health, can affect lycopene formation, development, and stability in watermelon (Naz et al., 2014; Perkins-Veazie et al., 2001). For example, lycopene and $\beta$-carotene content of watermelon tend to increase as temperature increases, likely due to temperature-sensitive pathways for carotenoid production (Naz et al., 2014; Oms-Oliu et al., 2009). However, in the current study there was no difference in lycopene content due to clear plastic mulch, which increased soil temperature $1-5{ }^{\circ} \mathrm{C}$ during the growing season.

In conclusion, this and similar studies in the region have shown that grafting watermelon can reduce verticillium wilt severity and increase fruit yield in Washington where soil population levels of $V$. dahliae range from 18 to $50 \mathrm{cfu} / \mathrm{g}$. A new finding of this study is that growing plants with clear plastic mulch may also reduce verticillium wilt severity and increase fruit yield even when soil population levels of $V$. dahliae are $50 \mathrm{cfu} / \mathrm{g}$. Actual $V$. dahlia soil population threshold levels are unknown for watermelon, and likely differ by region because of climate and other factors, and need investigation. Further research is also needed to better understand the yield potential of watermelon under different levels of verticillium wilt pressure. By testing soil before planting, growers in Washington can determine if measures may be needed to manage verticillium wilt. However, the additional cost of using grafted plants would need to be compared with the potential increase in yield to determine if this disease management strategy is cost-effective.

\section{Literature Cited}

AgWeatherNet. 2016. The Washington agricultural weather network. 15 Mar. 2015. <http://weather. wsu.edu/>.
Ashworth, L.J., Jr. and S.A. Gaona. 1982. Evaluation of clear polyethylene mulch for controlling Verticillium wilt in established pistachio nut groves. Phytopathology 72:243-246.

Berlanger, I. and M.L. Powelson. 2000. Verticillium wilt. The Plant Health Instructor. 16 Sept. 2013. $<$ http://www.apsnet.org/edcenter/intropp/lessons/ fungi/ascomycetes/Pages/VerticilliumWilt.aspx $>$.

Bruton, B.D., W.W. Fish, W. Roberts, and T.W. Popham. 2009. The influence of rootstock selection on fruit quality attributes of watermelon. Open Food Sci. J. 3:15-34.

Buller, S., D. Inglis, and C. Miles. 2013. Plant growth, fruit yield and quality, and tolerance to verticillium wilt of grafted watermelon and tomato in field production in the Pacific Northwest. HortScience 48:1-7.

Butterfield, E.J. and J.E. De Vay. 1977. Reassessment of soil assays for Verticillium dahliae. Phytopathology 67:1073-1078.

Calderon, R., C. Lucena, J.L. Trapero-Casas, P.J. Zarco-Tejada, and J.A. Navas-Cortes. 2014. Soil temperature determines the reaction of olive cultivars to Verticillium dahliae pathotypes. PLoS One, 9(10):e110664doi: 10.1371/ journal.pone.0110664.

Carpenter, J., L. Gianessi, and L. Lynch. 2000. The Economic impact of the scheduled U.S. phaseout of methyl bromide. Natl. Ctr. Food Agr. Policy. Bul. 756.

Cohen, R., Y. Burger, and C. Horev. 2007. Introducing grafted cucurbits to modern agriculture: The Israeli experience. Plant Dis. 91 (8):916-923.

Colla, G., C.M.C. Suarez, M. Cardarelli, and Y. Rouphael. 2010. Improving nitrogen use efficiency in melon by grafting. HortScience 45:559-565.

Cushman, K. 2009. Grafting techniques for watermelon. Univ. Fl. Coop. Ext. Serv. Gainesville, FL.

Davis, A.R., P. Perkins-Veazie, Y. Sakata, S. LopezGalarza, J.V. Maroto, S. Lee, Y. Huh, Z. Sun, A. Miguel, S.R. King, R. Cohen, and J. Lee. 2008. Cucurbit grafting. Crit. Rev. Plant Sci. 27:50-74.

du Toit, L.J., M.L. Derie, and P. Hernandez-Perez. 2005. Verticillium wilt in spinach seed production. Plant Dis. 89:4-11.

Dung, J.K.S. and J. Weiland. 2014. Verticillium wilt in the Pacific Northwest. PNW Plant disease management handbook. 25 Aug. 2015. $<$ http://pnwhandbooks.org/plantdisease/pathogenarticles/common/fungi/verticillium-wilt-pacificnorthwest>.

Elmore, C. L., J. J. Stapleton, C. E. Bell, and J. E. Devay. 1997. Soil solarization: A nonpesticida method for controlling diseases, nematodes, and weeds. Univ. California Div. Agr. Natural Recourses Publ. 21377.

Georgia Vegetable Team. 2000. Commercial watermelon production. Univ. Ga. Coop. Ext. Serv. Bul. 996.V.

Gordon, G.G., G.W. Foshee, S.T. Reed, J.E. Brown, and E.L. Vinson. 2010. The Effects of colored plastic mulches and row covers on the growth and yield of okra. HortTechnology 20:224-233

Gough, R.E. 2001. Color of plastic mulch affects lateral root development but not root system architecture in pepper. HortScience 36:66-68.

Guan, W., X. Zhao, R. Hassell, and J. Thies. 2012. Defense mechanisms involved in disease resistance of grafted vegetable. HortScience 47:164-170.

Hemphill, D. 2010. Oregon vegetables. 13 Sept. 2016. $<\mathrm{http} / /$ horticulture.oregonstate.edu/content/ watermelon- $0>$.
Huitron-Ramirez, M.V., M. Ricardez-Salinas, and F. Camacho-Ferre. 2009. Influence of grafted watermelon plant density on yield and quality in soil infested with melon necrotic spot virus. HortScience 44:1838-1841.

Johnson, S.J. 2012. Grafting eggplant, tomato, and watermelon to manage Verticillium wilt caused by Verticillium dahliae. MS Thesis, Washington State Univ., Pullman, WA.

Kabir, Z., R.G. Bhat, and K.V. Subbarao. 2004. Comparison of media for recovery of Verticillium dahliae from soil. Plant Dis. 88:49-55.

Katan, J. 1984. Soil solarization. In: C. Van Assche (ed.). Second International Symposium on Soil Disinfestation. Acta Horticulturae. Intl. Soc. Hort. Sci., Leuven, Belgium.

King, S.R., A.R. Davis, W. Liu, and A. Levi. 2008. Grafting for disease resistance. HortScience 43:1673-1676.

Klosterman, S.J., Z.K. Atallah, G.E. Vallad, and K.V. Subbarao. 2009. Diversity, pathogenicity, and management of Verticillium species. Annu. Rev. Phytopathol. 47:39-62.

Lee, J.-M. 1994. Cultivation of grafted vegetables, I. Current status, grafting methods, and benefits. HortScience 29:235-239.

Leonardi, C. and D. Romano. 2004. Recent issues on vegetable grafting. Acta Hort. 631:163-174.

Louws, F.J., C.L. Rivard, and C. Kubota. 2010 Grafting fruiting vegetables to manage soilborne pathogens, foliar pathogens, arthropods and weeds. Sci. Hort. 127:127-146.

Miles, C. L. Hesnault, S. Johnson, P. Kreider, and S. Dabirian. 2016. Vegetable grafting: Watermelon. Washington State Univ. Ext. Pub. FS100E. 15 Sept. 2016. <http://cru.cahe.wsu. edu/CEPublications/FS100E/FS100E.pdf>.

Nagata, M. and I. Yamashita. 1992. Simple method for simultaneous determination of chlorophyll and carotenoids in tomato fruit. J. Jpn. Soc. Food Sci. Tech. 39:925-928.

Naz, A., M.S. Butt, M.T. Sultan, M.N. Qayyum, and R.S. Niaz. 2014. Watermelon lycopene and allied health claims. EXCLI 13:650-666.

Oda, M. 2007. Vegetable grafting in Japan. In: J. Janick (ed.). Proc. XXVII IHC on Global Hort.: Diversity and Harmony. Acta Hort 759:175-180.

Oms-Oliu, G., I. Odriozola-Serrano, R. SolivaFortuny, and O. Martin-Belloso. 2009. Effects of high-intensity pulsed electric field processing conditions. Food Chem. 115:1312-1319.

Paplomatas, E.J., K. Elena, and A. Tsagkarakou. 2000. Screening tomato and cucurbit rootstocks for resistance to Verticillium dahliae. EPPO Bul. 30(2):239-242.

Paplomatas, E.J., K. Elena, A. Tsagkarakou, and A. Perdikaris. 2002. Control of Verticillium wilt of tomato and cucurbits through grafting of commercial varieties on resistant rootstocks. Acta Hort. (ISHS) 579:445-449.

Paroussi, G., F. Bletsos, G.A. Bardas, J.A. Kouvelos, and A. Klonari. 2007. Control of Fusarium and Verticillium wilt of watermelon by grafting and its effect on fruit yield and quality. Proc. IIIrd Balkan Symp. Veg. and Potatoes. Acta Hort. (ISHS) 729:281-285.

Perkins-Veazie, P., J.K. Collins, S.D. Pair, and W. Roberts. 2001. Lycopene content differs among red-fleshed watermelon cultivars. J. Sci. Food Agr. 81:983-987.

Proietti, S., Y. Rouphael, G. Colla, M. Cardarelli, M. De Agazio, M. Zacchini, E. Rea, S. Moscatello, and A. Battistelli. 2008. Fruit quality of mini-watermelon as affected by grafting and irrigation regimens. J. Sci. Food Agr. 88:1107-1114.

Qi, H.Y., T.L. Li, Y.F. Liu, and D. Li. 2006. Effects of grafting on photosynthesis characteristics, 
yield, and sugar content in melon. J. Shenyang Agr. Univ. 37:155-158.

Rajablarijani, H.R. and M. Aghaalikhani. 2011. Non-chemical weed control in winter canola (Brassica napus L.). In: Proc. 2nd Intl. Conf. Agr. Animal Sci., IPCBEE 22:30-34.

Sakata, Y., T. Ohara, and M. Sugiyama. 2007. The history and present state of the grafting of cucurbitaceous vegetables in Japan. Acta Hort. 731:159-170.

Sunseri, M. and D.A. Johnson. 2001. Verticillium wilt. Wash. State Univ. Coop. Ext. Bul. EB1908, Pullman, WA.

Tarara, J.M. 2000. Microclimate modification with plastic mulch. HortScience 35:222-228.
Tjamos, E.C. 1989. Problems and prospects in controlling Verticillium wilt. NATO ASI Series 28:441-446.

University of California. 2010. SoilWeb: Online soil survey browser. California Soil Resource Lab, Davis, CA. 12 Jan. 2016. <http://casoilresource.lawr.ucdavis.edu/s.

U.S. Environmental Protection Agency. 2015. The phase out of methyl bromide. Ozone layer protection: Regulatory Program. 6 Oct. 2015. <http://www.epa.gov/ozone/ $\mathrm{mbr} />$.

Wimer, J.A., C.A. Miles, and D.A. Inglis. 2015. Evaluating grafted watermelon for verticillium wilt severity, yield, and fruit quality in
Washington State. HortScience 50:13321337.

Woodward, J.E., T.A. Wheeler, M.G. Cattaneo, S. A. Russell, and T.A. Baughman. 2011. Evaluation of soil fumigants for management of Verticillium wilt of peanut in Texas. Plant Health Prog., doi: 10.1094/PHP-2011-0323-02-RS.

Wu, Y.F., Y. Chen, and Y.J. Zhao. 2006. Effect of pumpkin stocks on growth, development, yield, and quality of grafted muskmelon. Fujian J. Agr. Sci. 21:354-359.

Xu, C.Q., T.L. Li, and H.Y. Qi. 2005. Effects of grafting on the photosynthetic characteristics, growth situation, and yield of netted muskmelon. China Watermelon and Melon 2:1-3. 